\title{
Stick Dosing Unit
}

National Cancer Institute

\section{Source}

National Cancer Institute. Stick Dosing Unit. NCI Thesaurus. Code C53503.

A dosing unit equal to the amount of active ing redient(s) contained in a stick. 